\title{
The effects of phytase supplementation and dietary phosphorus level on performance and on tibia ash and phosphorus contents in broilers fed maize-soya- based diets
}

\author{
N. Ceylan ${ }^{1,4}$, S. Cangir ${ }^{1}$, M. Corduk ${ }^{3}$, A. Grigorov ${ }^{2}$ \\ and S.H. Golzar Adabi ${ }^{1}$ \\ ${ }^{1}$ Ankara University, Faculty of Agriculture, Department of Animal Science \\ 06110 Ankara, Turkey \\ ${ }^{2}$ Huvepharma AD, 1113 Sofia, Bulgaria \\ ${ }^{3}$ Ahi Evran University, Faculty of Agriculture, Department of Animal Science \\ 40100 Kirsehir, Turkey
}

(Received 4 June 2012; revised version 7 September 2012; accepted 15 November 2012)

\begin{abstract}
To test phytase efficiency, 4 dietary treatments including a positive control (T1), negative control (T2, containing $0.10 \%$ less total phosphorus than T1), negative control plus 500 FTU phytase (T3), and low-negative control plus 500 FTU phytase (T4, containing $0.13 \%$ less total phosphorus than T1) were used. Reducing the available phosphorus level of the broiler diet from $0.47 \%$ to $0.37 \%$ during the starter, and from $0.37 \%$ to $0.26 \%$ during the grower-finisher period significantly $(\mathrm{P}<0.01)$ depressed growth performance as compared with T1. Phytase supplementation significantly $(\mathrm{P}<0.01)$ improved the growth performance of the birds for both starter and grower periods. Tibia ash and phosphorus content in both the T3 and T4 groups were similar to T1 and higher $(\mathrm{P}<0.01)$ than in T2. Phytase supplementation of both negative control diets significantly $(\mathrm{P}<0.01)$ reduced the phosphorus level in excreta. It can be concluded that with phytase supplementation, the total phosphorus level in broiler diets can be decreased by $0.13 \%$.
\end{abstract}

KEY WORDS: broiler, phytase, growth performance, tibia ash, phosphorus

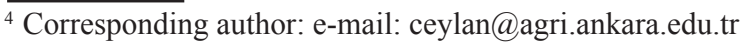




\section{INTRODUCTION}

A significant portion of the phosphorus $(\mathrm{P})$ in mature cereal grains and oilseeds is present as phytate $\mathrm{P}$ in mixed salts of phytic acid (myoinositol 1, 2, 3, 4, 5, 6-hexakis dihydrogen phosphate); phytic acid is a ubiquitous component of plantsourced feed ingredients which encompasses approximately two-thirds of total plant P (Hughes et al., 2009; Woyengo et al., 2010). Phytate P is utilized with an availability from $0 \%$ to $50 \%$ in poultry, depending on age and metabolic adaptation in critical circumstances, hence, expensive inorganic $P$ sources are routinely added to poultry diets to meet P requirements; this practice, however, ultimately, leads to a large portion of dietary $\mathrm{P}$ not being utilized by the animal but being excreted in faeces (Hughes et al., 2008; Woyengo et al., 2010). Several alternative methods have been devised over recent years in order to reduce the negative impact of phytate $\mathrm{P}$ on the environment and poultry performance. The use of one of these strategies, which includes the administration of microbial phytase, has increased remarkably since the early 1990s and has become a standard practice (Ceylan et al., 2003; Francesch and Geraert, 2009).

It must be mentioned that different phytases have various characteristics depending on the source from which they are derived, so they do not have the same effect and activity in the digestive tract. Therefore, each phytase preparation for poultry must be tested in vivo to ensure its efficacy (Onyango et al., 2005b; Hughes et al., 2008).

The current study was designed to evaluate the effect of microbial phytase supplementation on growth performance, tibia ash and $\mathrm{P}$ contents in tibia bones and in excreta of broilers.

\section{MATERIAL AND METHODS}

\section{Animals and management}

The research was carried out in a poultry house of the Animal Science Department of Ankara University. Two hundred and forty Ross 308 one-day-old male broiler chicks were randomly allocated to four dietary treatments, each with six replicates of ten birds placed in cage pens $(90 \times 85 \mathrm{~cm})$. The birds had a similar initial mean body weight of $40 \pm 0.1 \mathrm{~g}$. On the first day the ambient temperature was $33^{\circ} \mathrm{C}$, which was gradually decreased to $24^{\circ} \mathrm{C}$ at 3 weeks of age, maintained using a thermostatically controlled heater fan. The relative humidity of the house during the trail was $50 \% \pm 5 \%$. The house was artificially ventilated and during the trail all of the birds were kept under $24 \mathrm{~h}$ lighting regimens provided by incandescent lights. Each cage was equipped with automatic nipple drinkers, feeders were 
adjusted outside of the cage. Water and experimental diets (in mash form) were offered ad libitum. All birds were vaccinated against Gumboro disease on the $14^{\text {th }}$ day. The experimental design regarding the dietary treatments for starter and grower-finisher periods is shown in Table 1. The starter and grower-finisher diets were based on maize-soyabean meal and were offered to the birds from 0-21 and 21-40 days of age, respectively (Table 2). All diets were formulated to meet or exceede NRC (1994) requirements.

Table 1. Phytase added and available P level in experimental diets

\begin{tabular}{lccc}
\hline \multirow{2}{*}{ Treatments } & $\begin{array}{c}\text { Phytase activity } \\
\text { added, FTU/kg }\end{array}$ & starter diet & $\begin{array}{c}\text { Dietary P level, \% }{ }^{1} \\
\text { gror-finisher } \\
\text { diet }\end{array}$ \\
\hline T1-positive control & 0 & $0.70(0.47)$ & $0.612(0.37)$ \\
T2-negative control (NC) & 0 & $0.607(0.37)$ & $0.507(0.26)$ \\
T3-NC plus phytase & 500 & $0.609(0.37)$ & $0.504(0.26)$ \\
T4-low NC plus phytase & 500 & $0.57(0.34)$ & $0.468(0.23)$ \\
\hline
\end{tabular}

${ }^{1}$ paranthesis indicates available P level and calculated according to Selle and Ravindran (2007)

Table 2. Composition of starter and grower-finisher diets, $\mathrm{g} / \mathrm{kg}$ air-dry matter

\begin{tabular}{|c|c|c|c|c|c|c|c|c|}
\hline \multirow{3}{*}{ Indices } & \multicolumn{8}{|c|}{ Dietary treatments ${ }^{1}$} \\
\hline & $\mathrm{T} 1$ & $\mathrm{~T} 2$ & T3 & $\mathrm{T} 4$ & $\mathrm{~T} 1$ & $\mathrm{~T} 2$ & T3 & $\mathrm{T} 4$ \\
\hline & \multicolumn{4}{|c|}{ starter } & \multicolumn{4}{|c|}{ grower - finisher } \\
\hline \multicolumn{9}{|l|}{ Ingredients } \\
\hline maize & 497.7 & 507 & 507 & 510.5 & 526.6 & 536.4 & 536.4 & 538.6 \\
\hline soyabean meal & 384 & 383 & 383 & 381 & 371 & 370 & 370 & 369 \\
\hline fish meal & 40 & 40 & 40 & 40 & & & & \\
\hline sunflower oil & 45.2 & 42 & 42 & 41.3 & 66.5 & 63 & 63 & 62.5 \\
\hline limestone & 13.2 & 13.7 & 13.7 & 14.6 & 15.25 & 16 & 16 & 17 \\
\hline dicalcium phosphate & 9.3 & 3.7 & 3.7 & 2.05 & 11.45 & 0.54 & 0.54 & 0.37 \\
\hline $\mathrm{NaCl}$ & 4 & 4 & 4 & 4 & 4.15 & 4.15 & 4.15 & 4.15 \\
\hline L-lysine \% & 0.6 & 0.6 & 0.6 & 0.6 & 0.25 & 0.25 & 0.25 & 0.25 \\
\hline DL-methionine \% & 2.5 & 2.5 & 2.5 & 2.45 & 2.3 & 2.3 & 2.3 & 2.3 \\
\hline eral premix ${ }^{2}$ & 2.5 & 2.5 & 2.5 & 2.5 & 2.5 & 2.5 & 2.5 & 2.5 \\
\hline anticoccidia & 1 & 1 & 1 & 1 & & & & \\
\hline phytase pr & & & 0.1 & 0.1 & & & 0.1 & 0.1 \\
\hline $\mathrm{ME}, \mathrm{MJ} / \mathrm{kg}$ (cal & 12.83 & 12.83 & 12.83 & 12.83 & 13.39 & 13.39 & 13.39 & 13.39 \\
\hline \multicolumn{9}{|l|}{ Analysed } \\
\hline dry matter, \% & 90.08 & 89.84 & 89.36 & 90.16 & 90.20 & 90.12 & 90.30 & 89.74 \\
\hline crude protein,\% & 23.38 & 23.06 & 23.16 & 22.83 & 20.63 & 19.86 & 19.43 & 19.64 \\
\hline crude fat,\% & 7.91 & 7.58 & 7.89 & 7.93 & 9.51 & 9.69 & 9.38 & 9.22 \\
\hline crude ash,\% & 6.30 & 6.01 & 6.01 & 5.90 & 6.14 & 5.73 & 5.72 & 5.77 \\
\hline total P, \% & 0.70 & 0.607 & 0.609 & 0.57 & 0.612 & 0.507 & 0.504 & 0.468 \\
\hline phytase activity, FTU & - & - & 540 & 550 & - & - & 560 & 730 \\
\hline \multicolumn{9}{|c|}{$\begin{array}{l}\text { see Table } 1 ;^{2} \text { provides per kg of diet: mg: vit. A (all-trans-retinol) 3.6, vit. D (cholecalciferol) } \\
0.038 \text {, vit. E } 50 \text {, vit } \mathrm{K}_{3}, 5 \text {, vit. } \mathrm{B}_{1}, 3 \text {, vit. } \mathrm{B}_{2} 6 \text {, vit. } \mathrm{B}_{6}, 5 \text {, vit. } \mathrm{B}_{12}, 0.030 \text {, niacin } 25 \text {, Ca-D- } \\
\text { pantothenate } 12 \text {, folic acid } 1, \mathrm{D} \text {-biotin } 0.05 \text {, choline chloride } 400 \text {, apo-carotenoic acid ethyl } \\
\text { ester } 2.5 \text {, Mn } 80, \mathrm{Fe} 30, \mathrm{Zn} 60, \mathrm{Cu} 5, \mathrm{I} 2, \mathrm{Co} 0.5 \text {, Se } 0.15 ;{ }^{3} \mathrm{CYGRO}^{\circledR} ;{ }^{4} 5000 \mathrm{FTU} / \mathrm{g} \text {, see Material } \\
\text { and Methods }\end{array}$} \\
\hline
\end{tabular}


Analysis

Hostazym $^{\circledR} \mathrm{P}$ phytase, supplied by Huvepharma $\mathrm{AD}$, was used in the experimental diet. This preparation contains $5000 \mathrm{FTU} / \mathrm{g}$ according to the producer's declaration. The manufacturer recommends adding it to broiler diets at a rate of $100 \mathrm{~g} / \mathrm{ton}$.

Mortality was recorded daily, feed intake (FI) and body weight were recorded weekly. FI data in replications were corrected by withdrawing the calculated consumption of the dead bird. Body weight gain (BWG) and feed conversion ratio (FCR) were calculated for the periods of day 1-21 and 22-40. During the trial, birds that could not stand up because of twisted legs were recorded for incidence of leg problems. At the end of the experiment, 2 chickens per pen with a weight near the average were selected and killed by cervical dislocation for processing. The birds were weighed, plucked, and eviscerated. Carcass, drumsticks (with bones), breast meat (with bones), and abdominal fat were excised and weighed, then calculated as a percent of live body weight. The left tibia from each bird was excised, sealed in plastic bags and stored at $-20^{\circ} \mathrm{C}$ until further analysis.

Raw materials and diets were analysed for nutrient contents according to AOAC (2005). Phytase activity in diets was measured according to Gizzi et al. (2008). A unit of phytase activity was defined as the amount of inorganic phosphate released from myoinositol hexakisphosphate after $30 \mathrm{~min}$ incubation at $37^{\circ} \mathrm{C}$ with $100 \mu \mathrm{l}$ of extract (obtained by extracting $50 \mathrm{~g}$ of feed with $500 \mathrm{ml}$ distilled water) in $300 \mu$ acetate buffer ( $0.25 \mathrm{M}$; pH 5.5).

Before analysis, meat and fat were gently removed from tibia bones. The bones were dried overnight at $100^{\circ} \mathrm{C}$, extracted in ether for $6 \mathrm{~h}$, and burnt to ash in a muffle furnace at $600^{\circ} \mathrm{C}$. The ash from each tibia was used for phosphorus analysis according to AOAC (2005). On the last day of the experiment, approximately $50 \mathrm{~g}$ excreta samples from three replicates per group were collected, dried, and analysed for phosphorus content.

\section{Statistical analysis}

The data were analysed as a completely randomized block design with 4 dietary treatments and 6 replicates using the ANOVA procedure of the SAS (1996). All percentage data were subjected to arcsine square root transformation. When significant differences among groups were found, means were separated using the Tukey HSD test. 


\section{RESULTS AND DISCUSSION}

The performance results of the experiment are given in Table 3. Reducing the dietary calculated available phosphorus (aP) level of the broiler diet from $0.47 \%$ to $0.37 \%$ during the starter period and from $0.37 \%$ to $0.26 \%$ during the grower-finisher period significantly $(\mathrm{P}<0.01)$ decreased $\mathrm{BWG}, \mathrm{FI}$, and FCR as compared with the positive control (T1). The lowered body weight was due to the $\mathrm{P}$ deficiency in broilers fed at the $0.37 \%$ and $0.26 \%$ aP level, which is slightly below the recommended level for broilers during the starter and finisher periods, respectively (NRC, 1994). Some previous researchers have also reported poor performance of broilers fed diets with a P deficiency (Sohail and Roland, 1999; Bozkurt et al., 2006). The growth performance of T1 broilers during the first $21 \mathrm{~d}$ of age was approximately similar to what has been shown by Onyango et al. (2005a), Olukosi et al. (2007), and Woyengo et al. (2010) for chickens receiving adequate nutrients in their diets. Phytase supplementation significantly $(\mathrm{P}<0.01)$ improved growth performance of the birds and the best $(\mathrm{P}<0.001)$ FCR was obtained with the broilers fed diets $\mathrm{T} 3$ and $\mathrm{T} 4$.

Table 3. Effects of phytase supplementation on feed intake (FI) and feed conversion ratio (FCR) of broiler

\begin{tabular}{|c|c|c|c|c|c|c|c|c|c|}
\hline \multirow{2}{*}{ Treatments $^{1}$} & \multicolumn{3}{|c|}{$\mathrm{BWG}^{2}$, g/day } & \multicolumn{3}{|c|}{ FI, g/period } & \multicolumn{3}{|c|}{ FCR, kg feed /kg BWG } \\
\hline & $1-21$ & $22-40$ & $1-40$ & $1-21$ & $22-40$ & $1-40$ & $1-21$ & $22-40$ & $1-40$ \\
\hline & \multicolumn{9}{|c|}{ days } \\
\hline$\overline{\mathrm{T} 1}$ & $31.9^{\mathrm{a}}$ & $70.4^{\mathrm{ac}}$ & $50.2^{\mathrm{a}}$ & $0.840^{\mathrm{a}}$ & $2.17^{\mathrm{a}}$ & $3.01^{\mathrm{a}}$ & $1.25^{\mathrm{a}}$ & 1.62 & $1.49^{\mathrm{a}}$ \\
\hline $\mathrm{T} 2$ & $26.4^{\mathrm{b}}$ & $52.1^{\mathrm{b}}$ & $38.6^{\mathrm{b}}$ & $0.735^{\mathrm{b}}$ & $1.66^{\mathrm{b}}$ & $2.40^{\mathrm{b}}$ & $1.32^{\mathrm{b}}$ & 1.68 & $1.55^{\mathrm{b}}$ \\
\hline T3 & $34.8^{\mathrm{c}}$ & $74.3^{\mathrm{c}}$ & $53.6^{\mathrm{a}}$ & $0.904^{c}$ & $2.30^{\mathrm{a}}$ & $3.20^{\mathrm{a}}$ & $1.24^{\mathrm{a}}$ & 1.63 & $1.49^{\mathrm{a}}$ \\
\hline $\mathrm{T} 4$ & $31.6^{\mathrm{a}}$ & $75.8^{\mathrm{c}}$ & $52.6^{\mathrm{a}}$ & $0.832^{\mathrm{a}}$ & $2.27^{\mathrm{a}}$ & $3.11^{\mathrm{a}}$ & $1.25^{\mathrm{a}}$ & 1.58 & $1.47^{\mathrm{a}}$ \\
\hline $\mathrm{SEM}^{3}$ & 0.5 & 2.1 & 1.1 & 0.09 & 0.05 & 0.06 & 0.01 & 0.02 & 0.01 \\
\hline $\mathrm{P}$ & 0.01 & 0.001 & 0.02 & 0.0 & 0.0 & 0.0 & 0.004 & 0.1 & 0.03 \\
\hline
\end{tabular}

${ }^{1}$ see Table 1 ; ${ }^{\text {a-c }}$ means followed by different letters within columns are significantly different $(\mathrm{P}<0.05) ;{ }^{2} \mathrm{BWG}$ - body weight gain; ${ }^{3} \mathrm{SEM}$ - standard error of mean

The release of energy and amino acids by phytase is a disputable issue. Some research suggests up to $2 \%$ improvement in $\mathrm{AME}_{\mathrm{N}}$ values and amino acid digestibility, more conservative estimates are $0.062 \mathrm{MJ} \mathrm{ME} / \mathrm{kg}$, with no increase in amino acid availability (Leeson and Summers, 2005). In the present study, the better growth of broilers offered feeds containing phytase over the positive control birds can be attributed to the activity of the phytase used in the experiment. There were no significant differences, however, between T1 and T3 regarding FCR; the BWG of T3, which exceeded 5\%, was higher than in T1. Bozkurt et al. (2006) reported that the growth rate and FCR of broilers fed low-P diets containing microbial phytase are comparable with or even better than those obtained in broilers fed the standard P diets. Many researchers have observed an improvement 
due to dietary phytase supplementation in BWG and FI during the first $21 \mathrm{~d}$ of age (Denbow et al., 1995; Cabahug et al., 1999), whereas others reported no effect (Boling-Frankenbach et al., 2001). These contrasting results may be due to a number of factors, including phytase source (type, source, phytate content), and dietary characteristics (processing, vitamin $\mathrm{D}_{3}$ level, Ca:P ratio) (Ravindran et al., 1995).

As can be seen from Table 4, lowering the total $\mathrm{P}$ level of the diet by $0.13 \%$ to below the P requirement recommended by NRC (1994) resulted in significantly $(\mathrm{P}<0.05)$ higher mortality than in the positive control group. Phytase supplementation decreased the mortality and there were no significant differences among the positive control and phytase-supplemented groups. Mortality results in the current experiment confirm the findings of previous reports (Shirley and Edwards, 2003; Persia and Saylor, 2006; Jiang et al., 2011). Walk (2006) showed that the mortality rate in 42 -day old male broilers was $24 \%$ in birds fed the negative control diet, which contained $0.26 \%$ less total $\mathrm{P}$ than recommended by NRC (1994), and 6\% in birds fed $500 \mathrm{FTU} / \mathrm{kg}$ phytase-supplemented diets $(\mathrm{P}<0.05)$.

Table 4. Effects of phytase supplementation on mortality, bone development, excreta phosphorus

\begin{tabular}{lccccc}
\hline Treatments $^{1}$ & $\begin{array}{c}\text { Abnormal legs } \\
\%\end{array}$ & $\begin{array}{c}\text { Mortality } \\
\%\end{array}$ & $\begin{array}{c}\text { Tibia ash } \\
\% \text { of DM }\end{array}$ & $\begin{array}{c}\text { Tibia P \% of } \\
\text { dry-defatted } \\
\text { tibia }\end{array}$ & $\begin{array}{c}\text { Excreta P } \\
\% \text { in air dried } \\
\text { excreta }\end{array}$ \\
\hline T1 & $1.8^{\mathrm{a}}$ & $3.3^{\mathrm{a}}$ & 41.7 & $8.3^{\mathrm{a}}$ & $1.5^{\mathrm{a}}$ \\
$\mathrm{T} 2$ & $16.6^{\mathrm{b}}$ & $20.0^{\mathrm{b}}$ & 38.4 & $6.8^{\mathrm{b}}$ & $1.2^{\mathrm{b}}$ \\
$\mathrm{T} 3$ & $3.7^{\mathrm{a}}$ & $11.6^{\mathrm{ab}}$ & 41.5 & $8.4^{\mathrm{a}}$ & $1.2^{\mathrm{b}}$ \\
$\mathrm{T} 4$ & $1.8^{\mathrm{a}}$ & $11.6^{\mathrm{ab}}$ & 42.9 & $8.9^{\mathrm{a}}$ & $1.0^{\mathrm{c}}$ \\
$\mathrm{SEM}^{2}$ & 2.7 & 3.6 & 1.3 & 0.3 & 0.01 \\
$\mathrm{P}$ & 0.03 & 0.05 & 0.4 & 0.006 & 0.0001 \\
\hline
\end{tabular}

${ }^{1}$ see Table 1 ; ${ }^{\text {a-c }}$ values followed by different letters within columns are significantly different $(\mathrm{P}<0.05) ;{ }^{2} \mathrm{SEM}$ - standard error of mean

Leg problems were also affected by dietary treatments $(\mathrm{P}<0.05)$. Broiler chickens receiving the P-deficient diet (T2) had a higher incidence of abnormal legs in comparison with the remaining groups $(\mathrm{P}<0.05$; Table 4$)$.

In the present study, supplemental phytase did not influence tibia ash, which is in accordance with the results of Perney et al. (1993) and Pintar et al. (2004), but in contrast with those of Sohail and Roland (1999) and Woyengo et al. (2010) from maize-soyabean based diets.

In the T3 and T4 groups, as in the T1 group, tibia P content was higher than in $\mathrm{T} 2(\mathrm{P}<0.01)$, so presumably the added phytase liberated $\mathrm{P}$ from phytic acid molecules to satisfy the broilers' requirement for deposition of $\mathrm{P}$ in bones. This result is consistent with previous reports that phytase supplementation results in improved bone strength and bone mineralization in broilers fed low-P diets (Dilger et al., 2004; Woyengo et al., 2010). 
The content of $\mathrm{P}$ in broiler excreta at $40 \mathrm{~d}$ of age in group T4 was lower than in group $\mathrm{T} 1(\mathrm{P}<0.01$; Table 4). This result corroborates the findings of Waldroup et al. (2000) and Yan et al. (2000), who reported the reduction of excreta P output by approximately $25 \%$ to $28 \%$, respectively, when broiler diets were supplemented with phytase. Reported values for P level in broiler excreta vary widely, and can average even $2.1 \%$, with a range of $1.3 \%$ to $3.4 \%$ (Waldroup et al., 2000).

As shown in Table 5, no statistical differences were observed for carcass yields or individual part yields between treatments. Pillai et al. (2006) showed that in broilers fed diets with an adequate level of $\mathrm{Ca}$ and deficient level of $\mathrm{P}$ during the starter and grower periods, microbial phytase supplementation prevented the negative effects of P deficiency on carcass and breast yields. Also Scheideler and Ferket (2000) reported the lack of significant effects of exogenous phytase on broiler carcass yields.

Table 5. Effects of phytase supplementation on some carcass characteristics, \% of live body weight

\begin{tabular}{lcccc}
\hline Treatment $^{1}$ & $\begin{array}{c}\text { Carcass } \\
\text { yield }\end{array}$ & Drumsticks & $\begin{array}{c}\text { Breast } \\
\text { meat }\end{array}$ & $\begin{array}{c}\text { Abdominal } \\
\text { fat }\end{array}$ \\
\hline T1 & 68.9 & 29.0 & 33.1 & 0.9 \\
T2 & 67.7 & 30.1 & 33.3 & 0.8 \\
T3 & 70.1 & 28.8 & 33.1 & 1.1 \\
T4 & 71.2 & 28.4 & 34.3 & 1.3 \\
SEM $^{2}$ & 0.8 & 0.5 & 0.6 & 0.1 \\
P & 0.1 & 0.1 & 0.5 & 0.5 \\
\hline
\end{tabular}

${ }^{1}$ see Table $1 ;{ }^{2} \mathrm{SEM}$ - standard error of mean

\section{CONCLUSIONS}

It can be concluded that under the conditions used in the current study, phytase supplementation permits reducing the total $\mathrm{P}$ level of the broiler diets by up to $0.13 \%$ without any adverse effects on broiler growth and bone development. The cost benefits and lower pollution of the environment by broiler production are additional values of phytase supplementation.

\section{ACKNOWLEDGEMENTS}

We gratefully acknowledge Miss E. Golzar Adabi (Islamic Azad University, East Azarbayjan Science and Research Branch, Tabriz-Iran) who provided translation assistance. 


\section{REFERENCES}

AOAC, 2005. Association of Official Analytical Chemist, Official Methods of Analysis. $15^{\text {th }}$ Edition. Washington, DC

Boling-Frankenbach S.D., Peter C.M., Douglas M.W., Snow J.L., Parsons C.M., Baker D.H., 2001. Efficacy of phytase for increasing protein efficiency ratio values of feed ingredients. Poultry Sci. 80, 1578-1584

Bozkurt M., Cabuk M., Alcicek A., 2006. The effect of microbial phytase in broiler grower diets containing low phosphorous, energy and protein. J. Poultry Sci. 43, 29-34

Cabahug S., Ravindran V., Selle P.H., Bryden W.L., 1999. Response of broiler chickens to microbial phytase supplementation as influenced by dietary phytic acid and nonphytate phosphorus contents. I. Effects on bird performance and toe ash. Brit. Poultry Sci. 40, 660-666

Ceylan N., Scheideler S.E., Stilborn H.L., 2003. High available phosphorus corn and phytase in layer diets. Poultry Sci. 82, 789-795

Dilger R.N., Onyango E.M., Sands J.S., Adeola O., 2004. Evaluation of microbial phytase in broiler diets. Poultry Sci. 83, 962-970

Denbow D.M., Ravindran V., Kornegay E.T., Yi Z., Hulet R.M., 1995. Improving phosphorus availability in soybean meal for broilers by supplemental phytase. Poultry Sci. 74, 1831-1842

Francesch M., Geraert P.A., 2009. Enzyme complex containing carbohydrases and phytase improves growth performance and bone mineralization of broilers fed reduced nutrient corn-soybeanbased diets. Poultry Sci. 88, 1915-1924

Gizzi G., Thyregod P., Von Holst C., Bertin G., Vogel K., Faurschou-Isaksen M., Betz R., Murphy R., Andersen B.B., 2008. Determination of phytase activity in feed: interlaboratory study. J. AOAC Int. 91, 259-267

Hughes A.L., Dahiya J.P., Wyatt C.L., Classen H.L., 2008. The efficacy of Quantum phytase in a frty-week production trial using White Leghorn laying hens fed corn-soybean meal-based diets. Poultry Sci. 87, 1156-1161

Hughes A.L., Dahiya J.P., Wyatt C.L., Classen H.L., 2009. Effect of Quantum phytase on nutrient digestibility and bone ash in White Leghorn laying hens fed corn-soybean meal-based diets. Poultry Sci. 88, 1191-1198

Jiang S., Jiang Z., Zhou G., Chen Z., Li D., 2011. Non-phytate phosphorus requirements and efficacy of a genetically engineered yeast phytase in male lingnan yellow broilers from 1 to 21 days of age. J. Anim. Physiol. Anim. Nutr. 95, 47-55

Leeson S., Summers D.J., 2005. Commercial Poultry Nutrition. $3^{\text {rd }}$ Edition. University Books (Canada), pp. 270-271

NRC, 1994. Nutrient Requirements of Poultry. 9th revised Edition. National Academy Press. Washington, DC

Olukosi O.A., Cowieson A.J., Adeola O., 2007. Age-related influence of a cocktail of xylanase, amylase, and protease or phytase individually or in combination in broilers. Poultry Sci. 86, 77-86

Onyango E.M., Bedford M.R., Adeola O., 2005a. Efficacy of an evolved Escherichia coli phytase in diets of broiler chicks. Poultry Sci. 84, 248-255

Onyango E.M., Bedford M.R., Adeola O., 2005b. Phytase activity along the digestive tract of the broiler chick: A comparative study of an Escherichia coli-derived and Peniophora lycii phytase. Can. J. Anim. Sci. 85, 61-68

Perney K.M., Cantor A.H., Straw M.L., Herkelman K.L., 1993. The effect of dietary phytase on growth performance and phosphorus utilization of broiler chicks. Poultry Sci. 72, 2106-2114 
Persia M.E., Saylor W.W., 2006. Effects of broiler strain, dietary nonphytate phosphorus, and phytase supplementation on chick performance and tibia ash. J. Appl. Poultry Res. 15, 72-81

Pillai P.B., O’Connor-Dennie T., Owens C.M., Emmert J.L., 2006. Efficacy of an Escherichia coli phytase in broilers fed adequate or reduced phosphorus diets and its effect on carcass characteristics. Poultry Sci. 85, 1737-1745

Pintar J., Homen B., Gazic K., Grbesa D., Sikiric M., Cerny T., 2004. Effects of supplemental phytase on performance and tibia ash of broilers fed different cereals based diets. Czech J. Anim. Sci. 49, 542-548

Ravindran V., Kornegay E.T., Potter L.M., Ogunabameru B.O., Welten M.K., Wilson J.H., Potchanakorn M., 1995. An evaluation of various response criteria in assessing biological availability of phosphorus for broilers. Poultry Sci. 74, 1820-1830

SAS, 1996. SAS/STAT® User’s Guide, release 6.03 Edition. SAS Institute Inc. Cary, NC

Scheideler S.E., Ferket P.R., 2000. Phytase in broiler rations effect on carcass yields and incidence of tibial dyschondroplasia. J. Appl. Poultry Res. 9, 468-475

Selle P.H., Ravindran V., 2007. Microbial phytase in poultry nutrition. Anim. Feed Sci. Tech. 135, $1-41$

Shirley R.B., Edwards Jr. H.M., 2003. Graded levels of phytase past industry standards improves broiler performance. Poultry Sci. 82, 671-680

Sohail S.S., Roland D.A., 1999. Influence of supplemental phytase on performance of broilers four to six weeks of age. Poultry Sci. 78, 550-556

Waldroup P.W., Kersey J.H., Saleh E.A., Fritts C.A., Yan F., Stilborn H.L., Crum R.C., Raboy V., 2000. Nonphytate phosphorus requirement and phosphorus excretion of broilers fed diets composed of normal or high available phosphate corn with and without microbial phytase. Poultry Sci. 79, 1451-1459

Walk C., 2006. Evaluation of the efficacy of high levels of microbial phytase in broilers. MSc. Thesis. University of Missouri, Columbia (USA), pp. 115

Woyengo T.A., Slominski B.A., Jones R.O., 2010. Growth performance and nutrient utilization of broiler chickens fed diets supplemented with phytase alone or in combination with citric acid and multicarbohydrase. Poultry Sci. 89, 2221-2229

Yan F., Kersey J.H., Fritts C.A., Waldroup P.W., Stillborn H.L., Crum R.C., Rice D.W., Raboy V., 2000. Evaluation of normal yellow dent corn and high available phosphorus corn in combination with reduced dietary phosphorus and phytase supplementation for broilers grown to market weights in litter pens. Poultry Sci. 79, 1282-1289 